\title{
ORIËNTERENDE OPMERKINGS OOR ARTIKEL 36 VAN DIE NEDERLANDSE GELOOFSBELYDENIS
}

\author{
S.A. Strauss
}

\section{Omstrede aangeleentheid}

Sedert 1966 verskyn die moontlike wysiging van Artikel 36 van die Nederlandse Geloofsbelydenis aanhoudend op die agenda van die Algemene Sinode van die Nederduitse Gereformeerde Kerk. Hoe dit daar gekom het en wat in die afgelope byna twee dekades daaraan gedoen is, kan kortliks soos volg weergegee word"):

Die Gereformeerde Ekumeniese Sinode het in 1949 besluit en aanbeveel dat daar ' $n$ verandering aan Artikel 36 aangebring moet word, in lyn met wat die Gereformeerde Kerke in Nederland reeds in 1905 op hulle sinode besluit het, naamlik dat die volgende woorde geskrap word: “... om alle afgodery en valse godsdiens teen te gaan en uit te roei, die ryk van die Antichris te vernietig ..."

In 1966 het die GES 'n versoek in hierdie verband aan al sy lidkerke gerig. Die Algemene Sinode van die Nederduitse Gereformeerde Kerk het die saak na sy permanente Leerkommissie verwys.

In 1970 was daar ' $n$ versoek van die Federale Raad van Nederduitse Gereformeerde Kerke dat die hele aangeleentheid na die verskillende Sinodes verwys word. Die Algemene Sinode het hierdie versoek goedgekeur.

In 1974 het die Kommissie vir Leer en Protestantse Aksie egter gerapporteer dat die Sinodes nie almal gereageer het nie. Daar is weer besluit dat 'n gemotiveerde studiestuk aan die Sinodes deurgestuur moet word. Blykbaar het dit ook nie gerealiseer nie.

In 1978 dien die bekende studiestuk van F.N. van Niekerk voor die vergadering, en die Sinode verwys die saak na sy Algemene Kommissie vir Leer en Aktuele Sake.

By 1982 se Algemene Sinode hou die Algemene Kommissie vir Leer en Aktuele sake die volgende twee punte aan die vergadering voor:

(i) Die aanbeveling van die meerderheid dat die woorde hierbo genoem, geskrap word en in 'n voetnota aangebring word, aangesien dié gedagte nie uit die Skrif verantwoord kan word nie. Dit word ook opgemerk dat die nuwe vertaling van die belydenisskrifte, veral die woordjies "om sodoende", waarskynlik nie die bedoeling van die oorspronklike korrek weergee nie. 
(ii) Die aanbeveling van die minderheid dat die hele saak weer eens terug verwys word na die Algemene Kommissie vir Leer en Aktuele Sake vir verdere studie. Hierdie aanbeveling het die besluit van die Sinode geword. Daar was ook 'n voorstel voor die Sinode dat die nuwe vertaling wel die bedoeling van die oorspronklike weergee, maar dit is nie goedgekeur nie. Artikel 36 is dus tans nog steeds onder bespreking en bestudering.

Intussen het die aangeleentheid vanuit 'n ietwat ander hoek, as gevolg van onlangse gebeure, opnuut aktueel geword. Dit het begin met die debat oor die openingsgebed van die (voormalige) Presidentsraad, waarin na bewering die Naam van Christus verswyg sou gewees het. Daardeur is die problematiek van 'n christelike owerheid weer pertinent onder die aandag gebring.

Net so is daar ook rondom die referendum in 1983 gevra na die interpretasie van die Naam van God in die aanhef van die nuwe grondwet van die Republiek van Suid-Afrika, aangesien daar nou vir die eerste maal ' $n$ beduidende aantal Moslems en Boeddhiste deel van die parlement uitmaak. 'n Mens kan verwag dat hierdie debat in die komende jare voortgesit sal word.

Alles in ag genome, is dit nie te veel gesê nie dat artikel 36 van die Nederlandse Geloofsbelydenis (steeds!) 'n behoorlike ondersoek regverdig. Wat hier gebied word, is slegs voorlopige opmerkings om die leser te help oriënteer in die omvangryke problematiek.

\section{Noukeurige analise}

Die artikel kan ter wille van die oorsigtelikheid in vier onderafdelings verdeel word.

\subsection{Die owerheid is ' $n$ instelling van God}

Die volgende geloofswaarhede word bely:

*Ons goeie God het konings, vorste en owerhede aangestel.

* Hy doen dit vanweë die verdorwenheid van die menslike geslag.

* Dit is sy wil dat die wêreld geregeer word deur middel van wette en regerings.

* Die doel is: losbandigheid moet bedwing word, en alles onder die mense moet ordelik verloop.

*God gee aan die owerheid die "swaard."

Wat die Skrifbewys betref word daar by die oorspronklike Franse 
teks onder meer na die volgende tekste verwys ${ }^{21}$ :

Rom 13:1: "Elke mens moet hom onderwerp aan die owerhede wat oor hom gestel is. Daar is immers geen gesag wat nie van God kom nie, en die owerhede wat daar is, is daar deur die beskikking van God."

Spreuke 8:15: "Met my hulp regeer konings goed en laat maghebbers reg geskied."

Dan 2:21: "Hy wat ... konings afsit en konings aanstel."

Dan 5:18vv: "Die allerhoogste God het aan u voorganger Nebukadneser koningskap en mag, roem en eer gegee ... Hy moes erken dat die allerhoogste God mag het oor die koninkryke op aarde en daaroor aanstel wie Hy wil."

Hierdie eerste deel van ons belydenis spreek duidelik van die destydse reformatoriese verset teen die anabaptistiese radikalisme wat die owerheidsgesag nie in ere gehou het nie. Dat die owerheid ' $n$ instelling van God is, bly tans ook van toepassing op die steeds lewendige liberale leerstuk van die volksoewereiniteit. ${ }^{31}$

\subsection{Die taak van die owerheid}

\subsubsection{Die burgerlike taak}

Die belydenis stel dit kort en kernagtig dat dit die taak van die owerhede is om aan die staatsbestuur aandag te gee en daaroor te waak.

Die tersaaklike Skrifbewys is byvoorbeeld aanhalings uit Deut 1:16; 16:19; Jer 21:12 en 22:3 waar basies dieselfde staan, naamlik dat daar aan die koning van Israel gesê moet word: "So sê die Here: handhaaf die reg en wees regverdig." In die oorspronklike word ook na Rig 21:25 verwys: "In daardie tyd was daar nog nie 'n koning in Israel nie en elkeen het gedoen wat reg is in sy oë."

Oor dié tipiese taak van die owerheid behoort daar seker geen verskil van opvatting te bestaan nie.

\subsubsection{Die "geestelike" taak}

Onder mekaar gestel, word bely dat dit die taak van die owerheid is:

*om die heilige Woordbediening te beskerm

${ }^{*}$ om alle afgodery en valse godsdiens teen te gaan en uit te roei

+ $^{*}$ om die ryk van die Antichris te vernietig

*om die koninkryk van Jesus Christus te bevorder en orals te laat verkondig

* doel: dat God deur elkeen geëer en gedien word, soos $\mathrm{Hy}$ in sy Woord beveel. 
Die berugte beswaar teen Artikel 36 betref die tweede en derde sinsnede hierbo, met 'n + gemerk.

Oor die Skrifbewys in hierdie verband, weer enkele gegewens. Dit is opvallend dat die Geloofsbelydenis hier 'n eksklusiewe Ou-Testamentiese Skrifberoep hanteer. Onder meer die volgende Skrifgedeeltes word aangehaal:

Ps 101: Dawid sê dat hy in sy daaglikse regspraak die goddeloses in die land sal uitwis en die wat onreg doen uit die stad van die Here sal uitroei.

1 Kon 15:12: Asa doen wat reg is in die oë van die Here: hy het die tempelprostitute uit die land verban en al die afgodsbeelde verwoes.

2 Kon 23: Koning Josia bestryd die afgodery en laat die afgodspriesters op die altare slag.

Voordat daar in ' $n$ volgende paragraaf nader op hierdie problematiek ingegaan word, is dit nodig om ter wille van die historiese sin van hierdie moeilike sinsnede ook na die agtergrond daarvan in reformatoriese geskrifte te kyk. " Veral twee markante aspekte van Calvyn se behandeling van die taak van die owerheid word nie altyd raakgesien nie. Hy sê die owerheid dien ook daartoe dat afgodery, heiligskennis en lastering teëgewerk word, "opdat de openbare rust niet zou verstoord worden; opdat een ieder het zijne ongeschonden zou kunnen behouden; opdat de mensen ongedeerd met elkander zonden kunnen handelen; opdat eerbaarheid en ingetogenheid onder hen zou worden in ere gehouden." 5 , Die uitdruklike doe/ van die owerheid met die handhawing van God se eer is dus dat die openbare orde in die samelewing - dit wil sê die tipiese taak van die owerheid! - gehandhaaf word. Verder sê Calvyn ook dat die amp van die owerheid "zich uitstrekt tot beide tafelen der wet." ${ }^{\text {(6) }} \mathrm{Hy}$ beroep hom hiervoor op die heidense skrywers wat al beklemtoon het dat religieuse en burgerlike sake - dit wil sê godsdiens en politiek alles met mekaar te make het. En dan sê hy uitdruklik dat "Christelijke vorsten en overheden" hulle oor hulle sorgeloosheid in hierdie verband behoort te skaam. Die afleiding moet hieruit gemaak word dat Calvyn len ons Geloofsbelydenis) nie maar sommer oor die owerheid in die algemeen handel nie, maar spesifiek oor die christelike owerheid, bestaande uit mense met 'n christelike belydenis. Van hulle word verwag dat hulle ook moet let op die eise van die eersie tafel van die wet. Hulle het dus ook, as owerheid, 'n "geestelike" taak.

\subsection{Onderwerping aan die owerheid}

Ter wille van die volledigheid word die res van Artikel 36 ook geanaliseer. 
* Elkeen (van watter hoedanigheid, rang of stand ookal) is verplig om hom aan die owerhede te onderwerp.

* Belasting moet betaal en eer en onderdanigheid moet bewys word.

* Owerhede moet gehoorsaam word in alles wat nie met die Woord van God in stryd is nie.

* Voorbidding moet vir die owerhede gedoen word dat die Here hulle in al hulle handelinge mag bestuur.

*Doel: "sodat ons 'n rustige en stil lewe kan lei in alle godsvrug en eerbaarheid."

Behalwe na die bekende 1 Tim 2:2 en Rom 13 word hier ook onder meer verwys na Matt 17:27, waar die Here Jesus beveel dat belasting betaal moet word, ook vir Hom.

1 Pet 2:17: "Vrees God. Eer die keiser."

Tit 3:1: "Herinner die mense nadruklik daaraan dat hulle hulle aan owerheid en gesag moet onderwerp, daaraan gehoorsaam moet wees en bereid moet wees om alles te doen wat goed is."

Hierdie - hopelik onbestrede! - deel van die belydenis is in ons tyd baie aktueel. Ons leef immers in 'n tyd en ook op 'n kontinent swanger van revolusie. Groen van Prinsterer se gevleuelde woorde verdien steeds ons aandag: "Teenoor die revolusie die evangelie." Só alleen sal ons die hedendaagse teologie van die revolusie duidelik aan die kaak kan stel."

In die verbygang moet opgemerk word dat hier geen blinde onderworpenheid aan die owerheid beveel word nie. Op grond van noukeurige historiese ondersoek moet ons waarskynlik saam met Bremmer sê: "Er is verschil tussen revolutie en rebellie. Revolutie beoogt een totale omwenteling van het politiek en maatschappelijk bestel, rebellie betekent opstand tegen gezagsdragers die niet langer te verdragen zijn. "8) Dat daarmee egter nog nie alle konkrete probleme opgelos is nie spreek vanself!

\subsection{Die verwerping van die Wederdopers}

Die laaste paragraaf van Artikel 36 lui soos volg:

*Ons verfoei die Wederdopers en ander oproerige mense.

* Hulle verwerp die owerheidsgesag en die regeerders en wil die regsorde omverstoot.

* Hulle wil die gemeenskaplike besit van goedere invoer en die eerbaarheid wat God onder die mense ingestel het, versteur. 
Uit die voorafgaande opmerkings behoort die historiese sin van hierdie laaste deel van die artikel reeds sonder meer duidelik te wees. Daarby sal dit goed wees as die blywende aktualiteit van dié deel van ons belydenis raakgesien word. Dit kan immers nie ontken word dat ons in ons tyd ' $n$ herlewing van die Wederdoperdom beleef nie. En dan gaan dit nie om 'n politiek indifferente "doperse" instelling nie. Inteendeel, meermale word 'n oënskynlike pasifisme gepaar met 'n bewuste politieke aktivisme! Daarom moet daar duidelik tussen Calvinisme en radikalisme onderskei word. Dit is op sy minste tendensieus om te beweer dat die gereformeerde denke "die bloedbroer van die doperse absolutisme" sou wees. ${ }^{91}$

\section{Verskillende standpunte}

Met die verloop van jare het die omstrede sinsnedes in Artikel 36 verskillende standpunte uitgelok, waarvan hier opsommenderwys 'n paar meegedeel word.

\subsection{Skrapping}

Reeds in 1896 het A. Kuyper, H. Bavinck, F.L. Rutgers, L. Lindeboom en andere ' $n$ gravamen teen die derde paragraaf van Artikel 36 van die Gereformeerde Kerke in Nederland ingedien. By die sinode van 1905 is daar besluit om die gewraakte 21 woorde te skrap. ${ }^{10)}$ Dit bly tot vandag toe die offisiële posisie in die Gereformeerde Kerke in Nederland.

Die agtergrond van hierdie standpunt moet in die teologie van $A$. Kuyper gesoek word. ${ }^{11)}$ Op grond van sy leer van soewereiniteit in eie kring het hy hom beywer vir die vrye kerk en die vrye staat. Dit impliseer egter by Kuyper geen neutrale staat nie! Hy sê dat daar deur christelike owerheidspersone ' $n$ christelike staatslewe tot stand kom, waarvoor ons ons ook moet beywer. Omdat in sy tyd Nederland geen christelike volk meer was nie, moet volgens Kuyper die antitese beklemtoon word. Daar moet 'n aparte christelike politieke party gestig word - nie bedoel as 'n ghetto nie, maar as suurdeeg.

Kuyper hanteer ook die onderskeiding tussen die kerk as instituut en die kerk as organisme. As instituut mag die kerk hom nie direk met politieke sake inmeng nie. Maar op die terrein van die kerk as organisme vloei die besondere en die algemene genade as't ware inmekaar. Daarom het die kerk indirek wel deeglik 'n politieke taak.

Kuyper sê voorts dat daar sekere sake in die staatsbestuur voorkom wat 'n kerklike sowel as 'n burgerlike karakter dra, byvoorbeeld Sondagwetgewing, huweliksluiting, onderwys, militêre kapelane. In sulke sake moet die owerheid die kerk(e) se advies inwin. Aangesien die Gere- 
formeerde Kerke tans egter nie meer die staatskerk is nie, soos dit kort na die reformasie in Nederland wel die geval was, moet Artikel 36 van die NGB liewer gewysig word. Hoe kan die owerheid in Nederland byvoorbeeld kant kies vir die Gereformeerde Kerke teen die Roomse Kerk? Kuyper kies dus wel vir geloofs- en godsdiensvryheid, wat ook deur 'n christelike owerheid gehandhaaf moet word. Maar omdat hy nie geloof en politiek wou skei nie, kies hy egter nie vir 'n sogenaamde neutrale staat nie.

\subsection{Vervanging}

In 1953 stel die Gereformeerde Kerke in Nederland die volgende vervanging van die geskrapte gedeelte voor: "En aldus geroepen bij te dragen tot die opbouw van een Gode welgevallige samenleving der mensen heeft de Overheid, in onderwerping aan de Wet Gods, Zich verre houdende van alle volstrekte machtsoefening, op het haar zorg toevertrouwde terrein en met de haar toekomende middelaar, iedere belemmering voor de prediking van het Evangelie en voor geheel de heilige dienst van God weg te nemen, opdat het Woord des Heren zijn loop hebbe, het Koninkrijk van Jezus Christus voortgang vinde en alle antichristelijke macht worde tegengestaan."121

Agter hierdie vervangingsvoorstel lê andermaal duidelik die teologiese insigte van Kuyper, veral wat die beginsel van soewereiniteit in eie kring betref. Die Gereformeerde Ekumeniese Sinode het sy lidkerke in 1963 versoek om hierdie aanbeveling oor te neem. So het dit ook op die tafel van ons Algemene Sinode beland.

Polman vereenselwig hom met dié voorstel van die GES. Hy betreur die gang van sake op sy eie kerke se sinode van 1905 ten seerste en noem dit weinig stylvol. Enkele stene word uitgebreek maar die res word laat staan. ${ }^{13)}$ Wanneer hy verder op die saak ingaan, bevind hy dat Calvyn en de Brès se eksklusiewe Ou-Testamentiese Skrifberoep vir die omstrede woorde as sodanig nie verkeerd is nie. Aangesien die Nuwe Testament egter swyg oor die verhouding van die owerheid tot die kerk konkludeer hy: "Het is zonder meer duidelijk, dat het oude artikel boven deze klare gegevens van de Schrift uitgaat."14)

Voor ons Algemene Sinode van 1970 dien daar ' $n$ rapport van F.J.M. Potgieter en J.D. Vorster wat in hoofsaak met Polman se uiteensetting en gevolgtrekking ooreenstem. ${ }^{15}$ ) Die rapport ag die vervangingsvoorstel van die GES "Skriftuurlik verantwoord" en voeg daarby dat die oorspronklike Artikel 36 nie inaggeneem het dat die Ou-Testamentiese "teokrasie" tans nie meer op die verhouding tussen kerk en staat van toepassing is nie. ${ }^{16}$ । Hulle beveel derhalwe aan dat die oorspronklike 
bewoording geskrap en vervang word - iets waarvoor die Algemene Sinode tot op hede nog nie kans gesien het nie.

\subsection{Interpretering}

Nie almal was dit eens met die Gereformeerde Kerke in Nederland se vaste oortuiging nie. Op allerlei maniere is daar gepoog om die historiese (en natuurlik ook Skriftuurlike!) sin van die oorspronklike artikel te peil. Om dit ietwat speels uit te druk: Soos Bultmann met die mites wou maak, wil baie teoloë met Artikel $\mathbf{3 6}$ maak: dit moenie geëlimineer word nie, maar geïnterpreteer word!

H. Visscher het in 1939 'n belangrike boek oor hierdie onderwerp geskryf: De staatkundige beginselen der Nederlandse Geloofsbelijdenis. Kortliks kom sy standpunt, wat hy met baie argumente ondersteun, daarop neer dat die gewraakte woorde nie meer behoort tot die omskrywing van die taak van die owerheid nie, maar verstaan moet word as behorende tot die doe/ van die owerheid. Dit lyk nogal ietwat op ons nuutste Afrikaanse vertaling van Artikel 36: "om sodoende alle afgodery en valse godsdiens teë te gaan." Visscher sê dat ons dit so moet verstaan dat die owerheid sy hand moet hou aan die heilige kerkdiens, sodat deur middel van die Woordbediening die Antichris te gronde gerig en die afgodery uitgeroei kan word.

F.N. van Niekerk het in 1978 sy befaamde studiestuk: "Geen verandering nodig nie" by die Algemene Sinode ingedien. ${ }^{17)}$ Dit is 'n stuk wat nogal met baie emosie geskrywe is. As ek hom goed begryp, sluit hy in hoofsaak by die standpunt van $\mathrm{H}$. Visscher aan. Hy ontken heftig dat daar ooit in die geskiedenis sprake was van "'n bandelose slagting van andersdenkendes" deur mense wat die Nederlandse Geloofsbelydenis Artikel $\mathbf{3 6}$ onderskryf het. Hy verwys na die berugte kwessie van Servet se dood op die brandstapel en Calvyn se aandeel daarin, maar beklemtoon dat dit ' $n$ uitsonderlike geval was. Dit was nooit algemene beleid dat van 'n christelike owerheid verwag kan word om alle andersdenkendes sondermeer met eie doodstraf te dreig nie!

Polman oordeel dat Visscher se uitleg niks anders as inlegkunde is nie. ${ }^{18)}$ En Douma sê dat Visscher se "oplossing" meer skerpsinnig as oortuigend is. ${ }^{19)}$ Dit bly dus ' $n$ ope vraag of so ' $n$ interpretasie nie dalk die intensie van die oorspronklike teks oorspan nie.

Daarmee is alles egter nog nie gesê nie. Baie gereformeerdes bly steeds daarvan oortuig dat die skrapping van die omstrede woorde nie die enigste alternatief is nie. "Het is goed mogelijk aan deze woorden een zinvolle functie te geven", sê die Gereformeerde Politieke Verbond van die (vrygemaakte) Gereformeerde Kerke in Nederland. ${ }^{20)}$ Hierdie kerke 
het ná hulle kerklike breuk met die Gereformeerde Kerke in 1944 ook polities ' $n$ ander weg as die tradisionele (Kuyperiaanse) Antirevolusionêre Party, tans opgeneem in die Christelike Demokratiese Aksie, bewandel. Hoewel hulle offisieel die skrapping van die omstrede woorde aanvaar, het hulle ernstige besware teen die redes wat daarvoor aangevoer word. ${ }^{211}$

'n Bekwame woordvoerder in hierdie verband was $C$. van der Waal. Op sy kenmerkende sprankelende wyse hark hy 'n hele klomp materiaal bymekaar om te bewys dat die oorspronklike bewoording en bedoeling van Artikel 36 behou moet word. En dit is volgens hom dat dit nie die taak van die owerheid is "om met swaard en inkwisisie die valse godsdiens te ruïneer nie. Dit is sy taak om die hand te hou aan die heilige ministerie, sodat 'die swaard van die Woord' gehanteer kan word."22)

\subsection{Gevolgtrekking}

Die groot vraag is nou: Wat máák ons met Artikel 36? Miskien sal dit die maklikste wees om die bekende regsfilosoof Herman Dooyeweerd hierin te volg. Hy was naamlik van mening dat daar in ' $n$ kerklike belydenis streng gesproke geen plek vir 'n stuk oor die taak van die owerheid is nie. Die hele artikel kan dus maar uitgehaal word. ${ }^{23)}$ Maar die saak is kennelik nie só eenvoudig nie. Die kerk moet tog in sy belydenis die hele Woord van God naspreek - alles wat God geopenbaar het, ook oor die taak van die owerheid.

Miskien kom ons hier voor 'n egte dilemma te staan. Moet ons die gewraakte woorde skrap, of moet ons hulle met iets beters vervang? Maar daaragter lê nog 'n dieper vraag, naamlik hoe op aarde 'n kerklike belydenis gewysig word? Waarskynlik openbaar dit iets van ' $n$ kragteloosheid dat ons so sukkel met Artikel 36. Ons bely tog dat die (veranderbare) belydenis onderworpe is aan die (onveranderlike) Woord van God. Maar hoe ruk 'n mens nou 'n stuk uit 'n klassieke, tydbetrokke teks sonder dat die geheel verlore gaan?

Dit sal waarskynlik beter wees om die teks histories te interpreteer en dit in die lig van die oorspronklike bedoeling in die omstandighede van destyds te lees. In daardie geval moet ten minste op voetspoor van Calvyn beklemtoon word dat dit in Artikel 36 in die eerste plek oor 'n christelike owerheid gaan. En in die tweede plek moet dit wel as die taak van die christelike owerheid beskou word dat hy afgodery en antichristelike optrede moet uitroei, met die tipiese mag tot sy beskikking, vir sover dié optrede staatsondermynend is. ${ }^{24)}$

Wanneer daar egter onder ons geen konsensus oor die oorspronklike sin en bedoeling van Artikel 36 bereik kan word nie, sal daar ernstige 
oorweging geskenk moet word aan die formulering van 'n eietydse gereformeerde belydenis waarin die besware ondervang kan word, en die Woord van God met oortuiging nagespreek kan word.

\section{Kerk en staat}

Streng gesproke handel Artikel 36 nie oor "die staat" nie. Die bekende Koopmans maak die interessante opmerking dat "die staat" 'n abstraksie, 'n mite is. Aangesien die Bybel egter van die "owerheid" praat, kan 'n mens sê: "De figuur van den staat, die, aan zichzelf overgelaten, de neiging heeft daemonisch geladen te worden, wordt in het Nieuwe Testament gehumaniseerd." ${ }^{25}$ ) Tog kan dit die moeite werd wees om na te gaan watter prinsipiële riglyne daar vanuit Artikel 36 getrek kan word oor die baie brandende tema van die verhouding tussen kerk en staat.

Vooraf net eers 'n opmerking van historiese aard. In ons Afrikaanse geskiedenis het die verhouding tussen kerk en staat anders verloop as in Nederland. ${ }^{26)}$ Aanvanklik onder Nederlandse en later onder Engelse bewind het ons 'n sterk staatsinmenging in kerksake aan die Kaap gehad. Uiteindelik word die kerk se eie bevoegdheid darem erken deur die bekende Ordonnansie nommer 7 van 1843. Tog is die Kaapse tradisie selfs in die Transgariep tydens en na die Groot Trek voortgesit. Dit is interessant om te weet dat Piet Retief, toe hy op 11 Junie 1837 by Blesberg as goewerneur ingehuldig is, met ' $n$ uitdruklike verwysing na Artikel 36 van die Nederduitse Geloofsbelydenis, belowe het dat hy die Nederduitse Gereformeerde Kerk sou beskerm en dat hy niemand wat nie aan dié kerk behoort het in sy staatsbestuur sou aanstel nie. Ook in die Z.A.R. was die Nederduitsch Hervormde Kerk van 1858 tot 1886 staatskerk. Hoewel president Paul Kruger anders gedink het oor dié saak, het ons dus 'n lang tradisie van ' $n$ (ongeoorloofde) vermenging van kerk en staat.

In die twintigste eeu het die opvattings van Abraham Kuyper oor die selfstandige lewenskringe sterk by ons deurgewerk. Volgens die beginsel van die soewereiniteit in eie kring word daar ruimte gebied vir sowel die onderskeid as die samehang van kerk en staat. Kerk en staat bestaan afsonderlik sonder om afgesonderd van mekaar te wees (Heyns).

In die jongste verlede gaan daar ook sterk invloed van Karl Barth se beskouinge op ons uit. ${ }^{27)}$ In sy werk van 1946: Christengemeinde und Bürgergemeinde sê hy dat die gemeente van die Here 'n "eksemplariese" funksie ten opsigte van die owerheid het. Dit is 'n "voorbeeld" van wat op staatkundige terrein moet gebeur. ${ }^{28)}$

Wanneer Artikel 36 van die Nederlandse Geloofsbelydenis met Ar- 
tikel 67 van die Kerkorde van die Nederduitse Gereformeerde Kerk verbind word, kan die volgende uitgangspunte aangaande die verhouding tussen kerk en staat geformuleer word.

\subsection{Onderskeie maar nie geskeie nie}

Die kerk is soewerein in eie kring. (Kerkorde art 67.1) Ons moet hierdie stelling uitbrei deur te sê dat die staat ook soewerein in eie kring is. Dié twee terreine moet dus onderskei word. Alle vermenging soos dié van 'n "staatskerk" (waar daar 'n bevoorregte kerk in 'n bepaalde staat is) en ook van 'n "kerk-staat" (waar jy iets van 'n anabaptistiese utopiestaat kry waar daar net christene mag woon) moet vermy word. So iets is nie in lyn met ons belydenis of met ons Kerkorde nie. Terselfdertyd mag ons nie 'n teëstelling maak tussen ' $n$ christelike kerk en 'n neutrale lof selfs nie-christelike en onchristelike) staat nie. Onderskeie maar nie geskeie nie! Ons mag nie die kortsigtige beskouing handhaaf dat die kerk die enigste christelike instelling in die samelewing kan wees nie. Ons sou dus ook verkeerd loop as ons die op sigself wel korrekte beginsel dat die owerheid moet regeer "in algemene belang" sover sou voer dat ons naderhand moet toegee dat die owerheid nie anders kan as om neutraal te wees nie. Nee, die kerk bely 'n christelike owerheid.

\subsection{Onderwerping aan owerheidsgesag}

Artikel 67.2 van die Kerkorde sê dat die kerk as instituut hom aan die gesag en wette van die staat onderwerp, in soverre dit sy deelname aan die regsverkeer betref en nie met die Woord van God in stryd is nie. Hierdie uitgangspunt is duidelik in ooreenstemming met wat Artikel 36 stel.

\subsection{Godsdiensuryheid erken}

Ook die christelike owerheid moet die beginsel van godsdiensvryheid en verdraagsaamheid erken. (Vgl Artikel 67.3 van die Kerkorde). Niemand mag met die swaardmag gedwing word om in Christus te glo nie!: Ons sal vir onsself moet uitmaak of die gedagte van gewetensvryheid alleen maar terug herlei moet word na die Franse Revolusie, en of ons nie moet deurstoot na wat die Evangelie van Jesus Christus en die gebod van naasteliefde ons op hierdie gebied leer nie. Terwyl ons godsdiensvryheid erken, sal ons terselfdertyd die misbruik daarvan om die fondamente van die staatsgesag te ondergrawe streng moet afkeur.

\section{4 'n Christelike owerheidsbeleid gevra}

Ons sal moet bly pleit vir 'n christelike owerheidsbeleid. Die kerk aanvaar 
dit immers as sy heilige roeping om steeds profeties en getuigend die staat aan te spreek. (Artikel 67.4). As daardie staat dan bely dat hy 'n christelike beleid wil voer, het die kerk die reg en die plig om profeties te getuig dat sy beleid inderdaad christelik uitgevoer moet word. Die kerk het die volste reg om van mense wat op grond van hulle christelike politieke belydenis (of ' $n$ program van beginsels) tot die owerheidsamp verkies is, te verwag dat hulle dié belydenis sal handhaaf.

\section{NOTAS}

1. Vergelyk vir meer besonderhede die Handelinge van die Algemene Sinode 1982, $499-503$.

2. J.N. Bakhuizen van den Brink, De Nederlandse Belijdenisgeschriften, Amsterdam ${ }^{2} 1976,142$. C.G. Bos, Geloven en belijden, Groningen 1978 is myns insiens een van die beste hedendaagse kommentare op die NGB, veral wat die bespreking van die Skrifbewys betref. Vergelyk $101 \mathrm{vv.}$

3. G.F. de Vos Hugo, Die huidige boodskap van die Calvinisme op staatkundige en politieke terrein in Suid-Afrika, Bloemfontein 1946, 18: "Die Calvinis verwerp ook die liberalistiese demokrasie op grond daarvan dat ... dit op staatkundige en politieke terrein geen band aan die Wet van God meer erken nie, en in die plek daarvan gestel het die mandaat-gedagte van die teorie van volksoewereiniteit."

4. A.D.R. Polman, Onze Nederlandsche Geloofsbelijdenis IV, Franeker s.j., 266vv verwys uitvoerig na uitsprake van Calvyn, Beza en de Brès. Vergelyk ook W.J.G. Lubbe, "Calvyn en die staat". NGTT volume 5 (1964), 200-208.

5. Calvyn, Institutie IV, XX, 3 (vert A. Sizoo, Delft, s.j., 558).

6. Calvyn, a.w. IV, XX, 9 (566).

7. Vergelyk in hierdie verband die baie verdienstelike, maar helaas nog ongepubliseerde, doktorale proefskrif van J.M. Vorster, Die neo-Marxistiese politieke teologie in Suid-Afrika. 'n Gereformeerd-apologetiese studie, P.U. vir CHO, Potchefstroom 1984.

8. R.H. Bremmer, Reformatie en rebellie. Willem van Oranje, de calvinisten en het recht van opstand, Franeker 1984, 7.

9. D.J. Smit, "Wat beteken 'Status confessionis'?"' in G.D. Cloete en D.J. Smit (red.), 'n Oomblik van waarheid, Kaapstad 1984, 33. Smit verwys daar na die opstel van W.D. Jonker: "Kritiese verwantskap? Opmerkings oor die verhouding van die pneumatologie van Calvyn tot dié van die Anabaptisme" in E. Brown (red.), Ca/vyn aktuee/?, Kaapstad 1982, 72-87. Jonker betoog egter juis die teenoorgestelde. Hy praat van "twee verskillende soorte spiritualiteit", "twee verskillende teologiese struktuurtipes" (81).

10. Polman, a.w., 290-291.

11. Vergelyk vir 'n goeie oorsig van Kuyper se standpunt, met die nodige bronneverwysings, J. Douma, Politieke verantwoordelijkheid, Kampen 1984, 88vv. Meer uitvoerig is natuurlik A.P. Treurnicht, Die verhouding van die staat tot die kerk by Doktor Abraham Kuyper, Ph.D-proefskrif, Universiteit van Kaapstad 1956.

12. Polman, a.w., 293.

13. Ibid., 291.

14. Ibid., 299.

15. Handelinge Algemene Sinode 1970, 365-366. 
16. Polman, a.w., 297, sê egter: "Wij hebben gezien, dat Calvijn en Beza deze bizondere positie van Israel duidelijk hebben onderkend. Men heeft hun wel vaak verweten, dat zij voor dit uitzonderlijk karakter van Israël geen oog gehad zouden hebben. Dit is geheel onjuist."

17. Hande/inge Algemene Sinode 1978, 1108-1121.

18. Polman, a.w., 284.

19. Douma, a.w., 130.

20. Kerk en politieke partij, Groningen 1979, 39, met verwysing na P. Deddens en J. Francke.

21. Vergelyk L. Roeleveld: "Na-oorlogse reformatoriese besinning oor Artikel 36 van die Nederlandse Geloofsbelydenis (die amp van die owerheid)", TCW volume 14 (1978), $60-73$. Behalwe die verwysings hierin na die standpunt van $K$. Schilder kan ook na laasgenoemde se diktaat: Christelijke religie, Kampen5, s.j., 116 w., verwys word. Daar word Schilder gerapporteer dat hy sou gesê het: "Het schrappen van deze 21 woorden was onjuist ... Men heeft van deze zinsnede een caricatuur gemaakt in 1905 en ze toen geschrapt."

22. C. van der Waal, "Kerk en owerhede in die drie formuliere van enigheid", SHE volume 6 (1980), 124-144. Die aanhaling staan op 134.

23. Vergelyk Polman, a.w., 296.

24. Vergelyk die beredenering in paragraaf 2.2 .2 hierbo.

25. J. Koopmans, De Nederlandsche Geloofsbelijdenis, Amsterdam 1939, 186.

26. Vergelyk Frits Gaum, Die kerk en die toekoms van Suid-Afrika, Pretoria 1981, 28vv.

27. In 'n onlangse voordrag vermeld J.J.F. Durand naas Kuyper ook Barth se invloed op ons. Vergelyk sy "The prophetic task of the church vis-a-vis the state" in die GESpublikasie Church and nation, Grand Rapids 1981, 3-15.

28. J. Koopmans, De Nederlandsche Geloofsbelijdenis, Amsterdam 1939, 186.

26. Vergelyk Frits Gaum, Die kerk en die toekoms van Suid-Afrika, Pretoria 1981, $28 \mathrm{vv.}$

27. In 'n onlangse voordrag vermeld J.J.F. Durand naas Kuyper ook Barth se invloed op ons. Vergelyk sy "The prophetic task of the church vis-a-vis the state" in die GESpublikasie Church and nation, Grand Rapids 1981, 3-15.

28. Oorgedruk in T. Strohm en H.D. Wendland (red.), Kirche und moderne Demokratie, Darmstadt 1973, 14-54. Vergelyk die sentrale uitspraak (52): "Der rechte Staat muss in der rechten Kirche sein Urbild und Vorbild haben. Die Kirche existiere also exemplarisch." 